\title{
The Protection of Individual Choice: A Consistent Understanding of Religion Under the First Amendment
}

\author{
Gail Merel $\uparrow$
}

In 1968, an ordained minister sought to dismiss, on grounds of religious free exercise, a criminal indictment for the use of LSD and marijuana in the religious rites of a newly formed church whose official songs were "Puff, the Magic Dragon" and "Row, Row, Row Your Boat." More recently, inmates of a federal penitentiary have, on similar grounds, demanded steak and wine for use in a paschal celebration of their assertedly religious faith in the destruction of all prison authority. ${ }^{2}$ In New Jersey, proponents of teaching Transcendental Meditation (TM) in public schools have sought, conversely, to avoid the strictures of the establishment cause by arguing in federal district court that TM is not a religion, ${ }^{3}$ even though part of the TM initiation ceremony centers on a chant honoring "the One, the Eternal, the Pure, the Immovable" Shri Guru Dev:"

In these and other recent cases, ${ }^{5}$ courts have been directly asked to decide what is and what is not religion for purposes of the free exercise and establishment clauses of the first amendment. The task facing the courts in these cases has been complicated considerably by Supreme Court free exercise and establishment clause doctrine. In particular, the Court's willingness, in cases such as Wisconsin $v$. Yoder, ${ }^{6}$ to grant special exemptions under the free exercise clause for religiously motivated conduct appears to be in fundamental con-

$\dagger$ Member of the New York Bar.

United States v. Kuch, 288 F. Supp. 439, 444 (D.D.C. 1968).

2 Theriault v. Silber, 391 F. Supp. 578, 582 (W.D. Tex. 1975), vacated and remanded, 547 F.2d 1279 (5th Cir. 1977).

3 Malnak v. Yogi, 440 F. Supp. 1284 (D.N.J. 1977).

- Id. at 1307.

s See, e.g., Missouri Church of Scientology v. State Tax Comm'n, 560 S.W.2d 837 (Mo. 1977), appeal dismissed, $99 \mathrm{~S}$. Ct. 57 (1978). It has been reported that more than half the taxpayers of Hardenburgh, New York, have ordained themselves ministers of the Universal Life Church by repeating "hallelujah" at a mass town meeting and are now claiming exemptions on their residential property taxes as officers of an unincorporated church. N.Y. Times, Jan. 16, 1977, \&1, at 30 , col. 1 .

- 406 U.S. 205 (1972); cf. Sherbert v. Verner, 374 U.S. 398, 410 (1963) (holding unconstitutional, as applied to a Seventh Day Adventist, South Carolina's conditioning of unemployment compensation benefits on availability for Saturday work). But see Braunfeld v. Brown, 366 U.S. 599 (1961). 
flict ${ }^{7}$ with its insistence, in cases such as Lemon $v$. Kurtzman, ${ }^{8}$ that state aid to religion violates the command of governmental neutrality embodied in the establishment clause.

The apparent conflict between the two provisions has led some commentators to conclude that religion itself must be understood to mean something different in each of the two clauses, ${ }^{9}$ a definitional approach at least as unsatisfactory as the bifurcated theory of the two clauses on which it is premised. A very different and more widely held theory of the first amendment, originally advanced by Professor Philip Kurland more than 15 years ago, attempts to resolve both the problems of conflict and definition by applying a single principle of neutrality to both free exercise and establishment cases. ${ }^{10}$ Yet Kurland's neutrality principle renders the two clauses theoretically consistent only by prohibiting the sort of special protection of religious expression extended by the Supreme Court in its recent free exercise decisions. Upon close scrutiny, moreover, the neutrality approach cannot dispose completely of the definitional problem, as exemplified by the TM case.

This article presents a theory of the religion clauses that permits, consistently with the Court's broad reading of the free exercise guarantee, a unified definitional approach to religion in both free exercise and establishment clause cases. I shall argue that the fundamental principle underlying both religion clauses is the protection of individual choice in matters of religion-whether pro or con-and that governmental neutrality is required only with respect to religious and irreligious opinion. This clarification of the neutrality approach eliminates the problem of conflict and permits a development of religion clause doctrine that is consistent with the Supreme Court's treatment of other first amendment rights. On this basis, I present a definitional approach to the religion clauses that

7 See, e.g., Committee for Pub. Educ. \& Religious Liberty v. Nyquist, 413 U.S. 756, 788 (1973); Wisconsin v. Yoder, 406 U.S. 205, 220-21 (1972); Tilton v. Richardson, 403 U.S. 672 , 677 (1971); Walz v. Tax Comm'n, 397 U.S. 664, 668-69 (1970); Sherbert v. Verner, 374 U.S. 398, 414-17 (1963) (Stewart, J., concurring); id. at 422-23 (Harlan, J., dissenting); accord, Ely, Legislative and Administrative Motivation in Constitutional Law, 79 YALE L.J. 1205, 1313 (1970); Kurland, Of Church and State and the Supreme Court, 29 U. CHI. L. REv. 1, 26 (1961); Schwarz, No Imposition of Religion: The Establishment Clause Value, 77 YALE L.J. 692 (1968).

403 U.S. 602 (1971). See also Wolman v. Walter, 433 U.S. 229 (1977); Meek v. Pittenger, 421 U.S. 349 (1975); Committee for Pub. Educ. \& Religious Liberty v. Nyquist, 413 U.S. 756 (1973); Levitt v. Committee for Pub. Educ. \& Religious Liberty, 413 U.S. 472 (1973).

- See, e.g., L. Tribe, American Constitutional Law \& 14-6, at 827-28, 831 (1978); Note, Toward a Constitutional Definition of Religion, 91 HARv. L. REv. 1056, 1085 \& n.138 (1978).

10 Kurland, supra note 7, at 2-6. See also Ely, supra note 7, at 1313-27; Schwarz, supra note 7 , at 693-701. 
is in keeping with an expansive protection of individual conscience in matters of religion and the fundamental right of each individual to define his own religious beliefs.

\section{Neutrality and the Religion Clauses}

\section{A. The Kurland Approach}

In his highly influential article, published in 1961, Professor Kurland argued that the two religion clauses of the first amendment should be read as premised upon a single "neutrality" principle." Under Kurland's formulation, "religion may not be used as a basis for classification for purposes of governmental action, whether that action be the conferring of rights or privileges or the imposition of duties or obligations." 12 The principle is capable of simple application: any governmental action that can be justified on secular grounds is permissible, without exception, under both clauses, regardless of any coincidental effects upon religion; as long as the requisite secular purpose can be discerned, no further analysis is necessary. ${ }^{13}$ Such a neutrality principle offers a clear solution to the problem of conflict between the free exercise and establishment clauses. Because no one can be specifically protected, on the basis of his religious beliefs, from the operation of general laws, the free exercise clause affords no special assistance that might contravene the establishment prohibition. ${ }^{14}$ The application of Kurland's principle reflects his view that the task of defining religion is not properly a judicial one: since both direct and indirect consequences for religion are irrelevant, there is ordinarily no need to identify, much less to define, the meaning of religion. ${ }^{15}$

The Kurland principle lends coherence and simplicity to religion-clause doctrine essentially by extending to the free exercise clause the doctrine of neutrality that the Court had already developed for purposes of the establishment clause. "Neutrality" re-

"Kurland, supra note 7.

12 Id. at 5. For discussions in support of the neutrality thesis, see, for example, Ely, supra note 7, at 1314; Giannella, Religious Liberty, Nonestablishment, and Doctrinal Development Part II. The Nonestablishment Principle, 81 HARv. L. REv. 513, 527 (1968); Weiss, Privilege, Posture and Protection: "Religion" in the Law, 73 YALE L.J. 593, 617-18 (1964).

13 See Kurland's discussion of Cox v. New Hampshire and Braunfeld v. Brown in Kurland, supra note 7, at 40-41. See also Ely, supra note 7, at 1324-27.

" See Kurland's discussion of Hamilton v. Regents, Murdock v. Pennsylvania, and Braunfeld v. Brown, in Kurland, supra note 7, at 26, 48, 90. See Schwarz, supra note 7, at 693.

is See Kurland, supra note 7, at 48.

1" See School Dist. v. Schempp, 374 U.S. 203, 217-23 (1963). The approach is also consistent with early Supreme Court free exercise doctrine. See, e.g., Braunfeld v. Brown, 366 U.S. 
mains an attractive constitutional principle, one that the Court has continued to invoke as the touchstone of establishment clause doctrine. The difficulty with the Kurland formulation, however, is that it resolves the problem of conflict only at a cost of almost total emasculation of the free exercise provision. At a time when we have grown increasingly protective of individual rights in general, and of first amendment rights in particular, the neutrality principle affords religious free exercise claims only the most minimal sort of scrutiny long ago relegated to the non-first amendment area of economic regulation. ${ }^{17}$ The individual is permitted to believe whatever he pleases, but apparently even the most trivial secular purpose suffices to justify imposing a burden on the free exercise of those beliefs. ${ }^{18}$

Preferring a more generous approach to the free exercise guarantee, the Supreme Court, in its more recent decisions, has rejected neutrality as a free exercise standard, holding laws with acknowledged secular purposes to be invalid when those laws have interfered even indirectly with claimants' religious expression. ${ }^{19}$ The conflict between such special protection of religious free exercise and an establishment clause doctrine still rooted in neutrality has, ironically, been exacerbated by the more rigid secular purpose test elaborated in the Court's recent establishment clause cases. ${ }^{20}$ The Court's present three-part test ${ }^{21}$ of religious establishment includes a concept of entanglement and an examination of primary effects not contemplated by Kurland's neutrality formulation. ${ }^{22}$ These facets of the Court's inquiry, which have been particularly significant in the Court's decisions concerning aid to parochial schools, ${ }^{23}$ run directly

599 (1961); Prince v. Massachusetts, 321 U.S. 158 (1940); Reynolds v. United States, 98 U.S. 145 (1878).

17 See Kurland, supra note 7, at 89 ("Indirect burdens on religion, apparently like indirect burdens on interstate commerce, do not-almost by definition-violate the freedom of religion provision.").

is Kurland explicitly rejects any "method of weighing constitutional objectives" as a kind of " "pots and pans" " analysis. Id. at 96.

1" Wisconsin v. Yoder, 406 U.S. 205 (1972); Sherbert v. Verner, 374 U.S. 398 (1963); cf. Wooley v. Maynard, 430 U.S. 705 (1977) (holding on broad "freedom of thought" grounds that New Hampshire could not require the display of the state motto-"Live Free or Die"-on vehicle license plates).

20 See, e.g., Wolman v. Walter, 433 U.S. 229, 236 (1977) (Justice Black's plurality opinion found that the secular purpose strand of the test presented "no difficulty."). See also Committee for Pub. Educ. \& Religious Liberty v. Nyquist, 413 U.S. 756, 773 (1973).

23 See Lemon v. Kurtzman, 403 U.S. 602, 612-13 (1971).

2 See generally Kurland, supra note 7, at 1-6, 69-72.

2s See Wolman v. Walter, 433 U.S. 229 (1977); Meek v. Pittenger, 421 U.S. 349 (1975); Committee for Pub. Educ. \& Religious Liberty v. Nyquist, 413 U.S. 756 (1973); Levitt v. Committee for Pub. Educ. \& Religious Liberty, 413 U.S. 472 (1973); Lemon v. Kurtzman, 403 U.S. 602 (1971). 
counter to the Court's willingness, in cases such as Yoder, to grant special exemptions to various religious claimants.

Even though a return by the Court to the Kurland view in both free exercise and establishment cases might serve to reverse this obviously inconsistent approach to the religion clauses, such a sacrifice of free exercise protection would not resolve the equally fundamental problem of defining religion. Although the Kurland doctrine appears to avoid the task of defining religion in most cases, ${ }^{24}$ the secular purpose test ultimately cannot operate without a definition of religion, since the identification of a secular purpose necessarily depends upon the determination of what is not, in fact, religious. ${ }^{25}$ In the New Jersey Transcendental Meditation case, ${ }^{28}$ for example, teaching TM in the public schools can be justified on secular grounds only if TM is not, in fact, a religion. TM's "Science of Creative Intelligence" might, for example, be said to advance the public health and safety by providing a method for the attainment of greater productivity and tranquility. ${ }^{27}$ But surely it would not be permissible to teach Catholicism in the public schools, ${ }^{28}$ even though many individuals find it to be the greatest source of human happiness and tranquility. The teaching of Catholicism is seen as religiously motivated ${ }^{29}$ precisely because it is not disputed that $\mathrm{Ca}$ tholicism is a religion. Similarly, if TM is a religion, application of the neutrality principle would deny it the privilege of a public school audience; if TM is not a religion, its transmission through the public school system can be readily upheld on secular grounds. In either case, it is necessary to go outside of the neutrality test in order to locate a workable understanding of religion within the meaning of the first amendment.

\section{B. An Alternative Approach to the Religion Clauses}

1. The Protection of Individual Choice in Matters of Religion. Religious liberty in this country has long been understood to include

${ }^{24}$ See text at note 15 supra.

2 For example, the Supreme Court in Epperson v. Arkansas, 393 U.S. 97 (1968), could only have determined that Arkansas's anti-evolution statute lacked secular purpose by first knowing that the teaching of Darwinism offended a "fundamentalist sectarian conviction," id. at 108 , i.e., by recognizing the presence of a nonsecular, religious purpose.

23 Malnak v. Yogi, 440 F. Supp. 1284 (D.N.J. 1977).

${ }^{2}$ According to defendants in the TM case, practice of the TM technique operates to reduce stress. Memorandum of Law of Defendants in Opposition to Plaintiffs' Motion for Partial Summary Judgment at 26, Malnak v. Yogi, 440 F. Supp. 1284 (D.N.J. 1977) [hereinafter cited as Memorandum].

2 The Supreme Court has held unconstitutional the use of the state's tax-supported compulsory public school machinery for the dissemination of religious doctrines. McCollum v. Board of Educ., 333 U.S. 203 (1948).

23 The interrelationship between purpose and motive is articulated in Ely, supra note 7, at 1315-25; see text at notes 104-121 infra. 
not only a right of choice among different forms of belief, but a freedom of disbelief as well..$^{30}$ In the words of James Madison: "Whilst we assert for ourselves a freedom to embrace, to profess and to observe the Religion which we believe to be of divine origin, we cannot deny an equal freedom to those whose minds have not yet yielded to the evidence which has convinced us." ${ }^{31}$ Thus, under the free exercise clause, coercion in matters of worship, prayer, and belief is unconstitutional whether directed against the individual who merely refuses to worship "correctly" or against the individual who opposes the idea of worship altogether. Religious free exercise "embraces the right to maintain theories of life and of death and of the hereafter which are rank heresy to followers of the orthodox faiths." 32 Similarly, the establishment clause not only prohibits establishment of an official church, but also bars political support of any one religion, of all religions, or of any movement promoting disbelief in religion generally. ${ }^{33}$ Laws that favor "atheistical dogmas," as well as those that prefer sectarian views, run afoul of the establishment prohibition. ${ }^{34}$

If there is any single unifying principle underlying the two religion clauses, therefore, it is that individual choice in matters of religion ${ }^{35}$ should remain free: individual decisions are to be protected whether they operate for or against the validity of any or all

30 See Torcaso v. Watkins, 367 U.S. 488, 495 n.10 (1961); United States v. Ballard, 322 U.S. 78, 86 (1944) (citing Cantwell).

${ }^{31}$ Madison, To the Honorable the General Assembly of the Commonwealth of Virginia. A Memorial and Remonstrance I 4 (1785), reprinted in Everson v. Board of Educ., 330 U.S. 1, 66-72 (1947) [hereinafter citted as Memorial and Remonstrance].

${ }^{32}$ United States v. Ballard, 322 U.S. 78, 86 (1944); accord, Zorach v. Clauson, 343 U.S. 306, 325 (1952) (Jackson, J., dissenting).

3 The "establishment of religion" clause of the First Amendment means at least this: Neither a state nor the Federal Government can set up a church. Neither can pass laws which aid one religion, aid all religions, or prefer one religion over another. Neither can force nor influence a person to go to or remain away from church against his will or force him to profess a belief or disbelief in any religion.

Everson v. Board of Educ., 330 U.S. 1, 15 (1947); accord, Lemon v. Kurtzman, 403 U.S. 602, 612 (1971).

34 "Resolve that neither the State nor nation, nor both combined, shall support institutions of learning other than those ... unmixed with sectarian, pagan, or atheistical dogmas." McCollum v. Board of Educ., 333 U.S. 203, 218 (1948) (Frankfurter, J., concurring) (quoting President Grant's speech at Des Moines, reprinted in 22 CATH. WorLd 433 (1876)).

A law requiring five minutes of anti-religious polemics each morning in the public schools should violate the establishment clause as certainly as a law directing that the same few minutes be devoted to prayer. Cf. Engel v. Vitale, 370 U.S. 421 (1962) (holding unconstitutional the recitation of a nondemoninational prayer in public schools).

${ }^{35}$ Cf. School Dist. v. Schempp, 374 U.S. 203, 222 (1963) (establishment clause "withdrew all legislative power respecting religious belief or the expression thereof'). 
religious views. The establishment clause serves to protect individual choice from the pressures of an official viewpoint; ; $^{36}$ the free exercise clause proscribes the more direct contraints of interference with particular beliefs. ${ }^{37} \mathrm{By}$ their combination, the individual is freed from both the weight of government opinion and the oppressive effects of government regulation in order to believe or disbelieve as he chooses.

It is essential to distinguish religious belief from conscientious opinion unrelated to matters of religion and to recognize that the latter is not protected by the first amendment religion clauses. The authors of the free exercise and establishment provisions were concerned with the peculiar problems of religious discord and the need to prevent oppression based on religious differences. ${ }^{38}$ Their perception of the need for some special protection of religious conscience has not necessarily become outmoded; religious belief may still provide a basis for discriminatory classification. ${ }^{39}$ The rights of individual conscience in nonreligious matters, however, have received rather effective constitutional protection outside the rubric of the religion clauses. Conscientious speech is, of course, protected by the first amendment speech clause, as are symbolic forms of speech, including such acts of conscientious protest as flag desecration ${ }^{10}$ and the wearing of armbands in public school. ${ }^{41}$ Penumbral rights emanating from the first amendment have also been held to protect the private possession of obscene material ${ }^{42}$ and to preserve the right of conscientious choice with regard to contraception and abortion. ${ }^{43}$

34 Cf. Walz v. Tax Comm'n, 397 U.S. 664, 668 (1970) ("It is sufficient to note that for the men who wrote the Religion Clauses of the First Amendment the 'establishment' of religion connoted sponsorship, financial support, and active involvement of the sovereign in religious activity."); Note, Toward a Uniform Valuation of the Religion Guarantees, 80 YaLs L.J. 77, 85 (1970) ("In the establishment cases, the threat to free adoption is inducement, rather than enforcement").

IV Violations of the establishment clause, unlike the free exercise provision, generally do not depend upon any showing of direct constraint, see, e.g., Engel v. Vitale, 370 U.S. 421, 430 (1962), although the Court does at times view taxpayers as being forced to pay for some other party's religion in establishment cases, see, e.g., Everson v. Board of Educ., 330 U.S. 1,16 (1947).

ss See, e.g., Reynolds v. United States, 98 U.S. 145, 162-64 (1878); Everson v. Board of Educ., 330 U.S. 1, 27 (1947) (Jackson, J., dissenting). C. ANTIEAU, A. DownEY, \& E. RoBERTs, Frgedom From Frderal Establishament 123-42 (1964); 1 A. Stokgs, Church and State in the UNTTED STATES 555 (1950).

31 See, e.g., Prince v. Massachusetts, 321 U.S. 158, 176 (1944) (Murphy, J., dissenting).

- Spence v. Washington, 418 U.S. 405 (1974) (per curiam) (improper use of the flag); Smith v. Goguen, 415 U.S. 566 (1974) (application of statute against "contemptuous" treatment of the flag held void-for-vagueness).

"Tinker v. Des Moines Independent Community School Dist., 393 U.S. 503 (1969).

42 Stanley v. Georgia, 394 U.S. 557 (1969).

4 Roe v. Wade, 410 U.S. 113 (1973); Eisenstadt v. Baird, 405 U.S. 438, 455-60 (1972) 
Limiting the free exercise and establishment clauses strictly to matters of religion renders the definitional problem somewhat more manageable; ${ }^{44}$ such an approach, however, departs from dicta in the conscientious objector decisions implying that conscientious beliefs not traditionally regarded as religious may fall within the protection of the religion clauses..$^{45}$ According to Justice Douglas, any interpretation of the religion clauses that provides less than identical protection for nonreligious opinion may actually be unconstitutional. ${ }^{48}$ To protect acts of conscience in all matters, however, not only reaches beyond the intention of the clauses, but is both theoretically and practically illimitable. Government is ultimately premised upon the subordination of individual conscience to majority rule. Safeguards can, of course, be provided for minority rights, and checks may be placed on purely majoritarian rule; in the end, however, government functions by the passage of a single law, the making of a final decision, the determination of a particular course of action. To permit special exceptions for activities actually singled out by the first amendment is, in itself, administratively difficult. ${ }^{47}$ But to protect the exercise of conscience in all things would effectively render every citizen, at his own option, a law unto himself. ${ }^{48}$

2. The Elimination of Conflict: Irreligious vs. Nonreligious Opinion. The apparent conflict between the free exercise and establishment clauses stems from the grant of special exemptions to religious believers, a grant that individuals motivated by nonreligious concerns are prohibited from sharing. ${ }^{49}$ Such preferential treatment

(Dougtas, J., concurring).

"See Part III infra.

is See Gillette v. United States, 401 U.S. 437, 445-47, 454 (1971); Welsh v. United States, 398 U.S. 333, 342-43 (1970); United States v. Seeger, 380 U.S. 163, 180-83 (1965). Welsh and Seeger represent instances of statutory interpretation where, to avoid potential establishment problems, the Court found non-traditional beliefs to be "religious."

"Gillette v. United States, 401 U.S. 437, 469 (1971) (Douglas, J., dissenting) ("A classification of 'conscience' based on a 'religion' and a 'conscience' based on more generalized, philosophical grounds is equally invidious by reason of our First Amendment standards.").

"See Braunfeld v. Brown, 366 U.S. 599, 606, 608-09 (1961).

is Cf. J. LOCKE, The SECOND TREATISE OF GOVERNMENT \& 97 ('[E]very man, by consenting with others to make one Body Politick under one Government, puts himself under an Obligation to every one of that Society, to submit to the determination of the majority . . . or else this original Compact . . . would signifie nothing, and be no Compact, if he be left free, and under no other ties, than he was in before in the State of Nature.").

- See, e.g., Sherbert v. Verner, 374 U.S. 398, 415 (1963) (Stewart, J., concurring):

In the words of the Court in Engel $v$. Vitale, . . . the Establishment Clause forbids the "financial support of government" to be "placed behind a particular religious belief."

To require South Carolina to so administer its laws as to pay public money to the appellant under the circumstances of this case is thus clearly to require the State to violate the Establishment Clause as construed by this Court. 
of religious over nonreligious belief appears to violate the establishment clause. This view of the religion clauses, however, fundamentally misconceives the nature of government impartiality that is constitutionally required: the religion clauses do not mandate government neutrality with respect to religious and nonreligious belief, because the very essence of the political compromise embedded in the establishment clause is that government must itself remain secular, or politically nonreligious, at all times. ${ }^{30}$ The appropriate dichotomy is between religion and irreligion, not between religion and nonreligion: government must remain neutral, not between those who believe and those who hold no religious viewpoint, but between those who favor and those who oppose some or all religious views."1 To the extent that the members of the Court have confused the two, ${ }^{52}$ they have set for themselves the rather illogical task of imposing an impartiality between religious and nonreligious opinion upon a government whose opinions are supposed to be nothing but nonreligious. And they have concerned themselves with the need to avoid establishing a "religion of secularism" is ultimately premised upon a wholly secular politics. These attempts to place conduct unrelated to issues of religion on a par with religious free exercise are simply not relevant to the principle of choice underlying the religion clauses of the first amendment.

No establishment problems arise from the active protection of religious and irreligious free exercise. As long as any special protection accorded the exercise of religious belief is also made available to the expression of antireligious views, the free exercise provision cannot be said to favor one religious view over another in violation of the establishment clause. It is true that, at any particular time, the state may allow one group with religious concerns to do something another group cannot, but the same may be said in regard to the state's protection of free speech. If at any point in time the law is used to protect an anarchist's right to speak, this does not mean that the government is pro-anarchy, or that it is favoring anarchist sympathizers. It means, instead, that the law is being used to ensure that all constitutionally protected speech is protected equally-at

so Cf. Memorial and Remonstrance, supra note 31, $\uparrow 1$; accord, McCollum v. Board of Educ., 333 U.S. 203, 212 (1948); Everson v. Board of Educ., 330 U.S. 1, 26-27 (1947) (Jackson, J., dissenting).

s1 See Schwarz, supra note 7, at 698-99, 719 (distinguishing "religion," "irreligion," and "nonreligion").

s2 See, e.g., Epperson v. Arkansas, 393 U.S. 97, 104 (1968); Sherbert v. Verner, 374 U.S. 398, 416 (1963) (Stewart, J., concurring); Torcaso v. Watkins, 367 U.S. 488, 495 (1961).

s3 School Dist. v. Schempp, 374 U.S. 203, 225 (1963). 
whatever time such protection may be required. Under the establishment clause, impartiality remains similarly undisturbed as long as the government protects the exercise of all beliefs in matters of religion without exception. Thus, for example, so long as children who attend private schools are as free to learn the irrelevance of religious belief as they now are to be trained in the tenets of a specific religion, ${ }^{54}$ government cannot, by excusing them from public school attendance requirements, be said to endorse either religious position, though both do benefit by the exemption.

The distinction between nonreligious or secular matters on the one hand and religious and irreligious opinions on the other is a critical one. The religion clauses serve to limit state interference in religious matters, to ensure that "opinions in Religion do not bend to those of the Legislative authority." 55 The individual is to be free from political pressure in relation to the expression of belief concerning fundamental matters of life and death, creation, and moral law. ${ }^{58}$ Thus the religious colporteur ${ }^{57}$ and the proselytizer of antireligious beliefs alike are protected by the free exercise clause. The speaker whose message concerns purely secular, though important, matters, however, is not exercising any sort of conscientious belief with respect to religion. The sincerity or intensity with which his beliefs are held does not render them any less secular or nonreligious; his constitutional protections must lie outside of the religion clauses under the more general rubric of free speech.

This distinction between irreligion and nonreligion can be illustrated in the context of the conscientious objector cases. An individual might well object to participation in war efforts serving to support religious beliefs he conscientiously opposes. Military action on behalf of the State of Israel, for example, might lead some to seek conscientious objector status on irreligious or anti-religious grounds. ${ }^{58}$ But such a claim is really quite different in nature from purely nonreligious and secular objections. Thus in a case like Welsh $v$. United States, ${ }^{59}$ for example, where Justice Harlan in his concurrence foresaw establishment problems in failing to grant con-

"Cf. Pierce v. Society of Sisters, 268 U.S. 510, 534 (1925) (upholding the right of parents and guardians to send their children to private, Catholic schools).

ss Memorial and Remonstrance, supra note 31, II 9.

st Cf. United States v. Ballard, 322 U.S. 78, 86 (1944) (the first amendment "embraces the right to maintain theories of life and of death and of the hereafter which are rank heresy to followers of the orthodox faith").

${ }^{37}$ See, e.g., Murdock v. Pennsylvania, 319 U.S. 105 (1943); Largent v. Texas, 318 U.S. 418 (1943); Jamison v. Texas, 318 U.S. 413 (1943).

ss See note 150 infra.

3938 U.S. 333 (1970). 
scientious objector status to a draftee whose beliefs were unrelated to any religious conviction, ${ }^{60}$ no establishment concerns were truly at stake. Welsh insisted that his conscientious objections were unrelated to any form of religious conviction, characterizing his beliefs "as having been formed "by reading in the fields of history and sociology." "61 Although the record makes clear that Welsh's views were sincerely and conscientiously held, ${ }^{82}$ his objections were based solely upon secular considerations arrived at in much the same way that every citizen makes judgments about the wisdom and efficacy of prevailing public policy. ${ }^{.3}$ Congress might choose to grant conscientious objector status to such forms of belief, ${ }^{84}$ but neither the establishment nor the free exercise clause mandates protection of such nonreligious views. It is only the expression of beliefs in relation to religion-whether pro or con-that has been singled out for special attention by the language of the first amendment..$^{65}$

\section{Operation of the Reugion Clauses}

The Supreme Court could do much to clarify religion clause doctrine by recognizing that the central value underlying both the establishment and free exercise provisions is the protection of individual choice in matters of religion and that an expansive protection of all such choices does not constitute an impermissible "establishment of religion." Recognition of this principle permits a bolder application, in religion clause cases, of a number of doctrines already developed by the Court for resolving other difficult constitutional issues. These correlative doctrines in turn provide a sounder theoretical basis for resolving the problem of defining religion.

" Id. at 344,356 .

"Id. at 341 .

12 Id. at 337 .

Id. at 342 .

"Indeed, the majority in Welsh concluded that Congress had intended that the statute include persons whose objections rested upon such considerations. Id. at 341-42.

is Thus the Supreme Court's decision in Walz v. Tax Comm'n, 397 U.S. 664 (1970), to uphold New York's grant of property tax exemptions to religious organizations is erroneous, unless New York's statutory exemption for " 'religious, bible, tract, charitable, benevolent, [and] missionary ... purposes," " id. at $667 \mathrm{n.1}$, is interpreted to include atheistic or agnostic groups. The fact that religious groups receive no better treatment than certain nonreligious groups does not lessen the unconstitutionality of a statute that discriminates against organizations whose religious views are unfavorable to belief in religion.

The same difficulty pertains to the present federal exemptions. See I.R.C. $\$ \& 170(c)$, 501(c)(3), 511(a)(2). 


\section{A. A Broad Free Exercise Guarantee}

Once it is recognized that the establishment clause in no way mandates governmental neutrality between religious and nonreligious opinion, both religious liberty and the freedom of irreligious expression can take their proper places among the other "preferred" freedoms of the first amendment..$^{80}$ Under this approach, there is no reason not to treat the free exercise right as coextensive with the right of free speech. ${ }^{67}$ Indeed, the kind of alternate-means analysis already developed by the Supreme Court in cases of speech-related conduct, and used by the Court in some cases of religious free exercise, ${ }^{68}$ can properly be used in all free exercise cases in order to protect religious claims under the first amendment.

The 1939 case of Schneider $v$. State ${ }^{68}$ exemplifies the alternatemeans approach. Rejecting a minimalist standard of mere "rationality" for the review of statutory restraints, the Supreme Court in Schneider invalidated four ordinances that had, in order to prevent littering, prohibited the distribution of handbills on public streets. The Court could conceivably have sustained these ordinances as reasonable regulations of the time, place, and manner in which rights of speech can be exercised in a public forum..$^{70}$ Instead, it chose to apply a more stringent test of constitutionality:

We are of opinion that the purpose to keep the streets clean and of good appearance is insufficient to justify an ordinance which prohibits a person rightfully in a public street from handing literature to one willing to receive it. . . This constitutional protection does not deprive a city of all power to prevent street littering. There are obvious methods of preventing littering.

* Cf. Murdock v. Pennsylvania, 319 U.S. 105, 115 (1943) ("Freedom of press, freedom of speech, freedom of religion are in a preferred position."); Wisconsin v. Yoder, 406 U.S. 205, 214 (1972) ("The values underlying [the religion clauses] . . . have been zealously protected"). See also United States v. Ballard, 322 U.S. 78, 92 (1944) (Jackson, J., dissenting) (religious speech is, under the Constitution, entitled to greater protection than nonreligious speech).

"7 Cf. Clark, Guidelines for the Free Exercise Clause, 83 Harv. L. Rev. 327, 336 (1969) ("identification of [religious freedom and freedom of speech] makes the free exercise clause redundant . . . . nor can free speech justifications explain the right to refrain from Saturday work, as in Sherbert, . . . since the symbolic qualities of such acts are minimal and the believer's motivation is not primarily one of communication.").

4s See text and notes at notes 80-95 infra.

308 U.S. 147 (1939).

70 The Supreme Court has upheld, for example, an absolute ban on "loud and raucous" speech (sound trucks) where other means of communication in the public streets remained open. Kovacs v. Cooper, 336 U.S. 77 (1949). 
Amongst these is the punishment of those who actually throw papers on the streets. ${ }^{\text {.1 }}$

Though an ordinance may be, on its face, unrelated to the suppression of free speech, if its effect is to suppress speech unnecessarily, or to an extent greater than that of available alternative means, then its constitutionality must fall in the balance against important first amendment rights. Application of this less-drasticmeans test has been more recently cited with approval by the Supreme Court in other handbill and anti-littering cases. ${ }^{72}$

The alternate-means test seems appropriately available for use in cases where statutes neutral on their face may also restrict the right of religious free exercise when applied in a particular case. ${ }^{73} \mathrm{~A}$ balancing of ends may be sufficient to protect religious or irreligious expression from intrusions relating to unimportant or insubstantial governmental interests, but by itself it provides inadequate protection of religious belief where substantial governmental interests are present. Since an unimportant state interest should never operate to restrict the right of free exercise, the determinative question is whether an important governmental interest is involved that, on balance, cannot be advanced by alternative means less restrictive of first amendment rights. A test of alternative means, in contrast

" Schneider, 308 U.S. at 162.

72 E.g., Talley v. California, 362 U.S. 60, $62-63$ (1960); Jamison v. Texas, 318 U.S. 413, 416 (1943). In 1968, the Supreme Court announced a much more restrictive test to be applied in cases of speech-related conduct where the governmental interest is unrelated to the suppression of free expression. United States v. O'Brien, 391 U.S. 367, 377 (1968). Since, however, virtually no state regulation would be rendered invalid by the $O^{\prime} B r i e n$ formulation, see Ely, Flag Desecration: A Case Study in the Roles of Categorization and Balancing in First Amendment Analysis, 88 HARv. L. Rkv. 1482, 1485-87 (1975), and since the Supreme Court chose not to follow O'Brien only three years later in Cohen v. California, 403 U.S. 15, 18 (1971) (distinguishing O'Brien unpersuasively on the ground that Cohen's wearing of a lettered jacket constituted pure speech), the Schneider formulation still seems most appropriate for use in the areas of both free speech and free exercise. But cf. Note, The Speech and Press Clause of the First Amendment as Ordinary Language, 87 HaRv. L. Rev. 374, 384-86 (1973) (the speech clause is concerned with the quality of speech in general, rather than with protecting the particular speech of individuals). For an argument that a less-drastic-means analysis is unworkable as a means of protecting first amendment rights, see Note, Less Drastic Means and the First Amendment, 78 YaLE L.J. 464 (1969).

73 See Wooley v. Maynard, 430 U.S. 705 (1977). The analogy between the free exercise and free speech protections seems valid despite the absence of an equivalent provision prohibiting all laws respecting an establishment of speech. While the state may, consistently with the free speech clause, take a position generally in matters of public concern, the state may not, by virtue of the establishment prohibition, take a position in matters of religious opinion. The neutral protection of all forms of expression is not, however, equivalent to the endorsement of any one in particular; the establishment prohibition does not require a free exercise test more restrictive of individual rights than that applied in the area of free speech. Contra, Kurland, supra note 7, at 52. 
to a balancing of ends, will work to invalidate laws serving even substantial governmental interests if such interests can be implemented by less intrusive means and if, on balance, any resulting loss in the effectiveness of such alternative means is offset by a distinct benefit to religious or irreligious free exercise. ${ }^{74}$ Moreover, because this test affords an expansive protection of free exercise rights, it also provides a principled basis for handling claims for the special protection, including the special exemption, of particular forms of religious or irreligious expression.

In Wisconsin v. Yoder, ${ }^{75}$ for example, explicit application of an alternative-means analysis could have helped to clarify the basis of the Court's decision to exempt Amish children from the operation of compulsory school attendance laws. ${ }^{78}$ Given the state's goal in Yoder-preparing its citizens to participate intelligently and selfsufficiently in a free system of government- ${ }^{77}$ and given the state's chosen means of executing that goal-compulsory education through age sixteen-the appropriate question to ask was whether any marginally greater effectiveness of the state's chosen means, when balanced against the effectiveness of available alternatives, could justify any incremental burdening of individual free exercise. In such a balance of means, even the state's substantial interest in education cannot be said, on the facts in Yoder, to justify compelling Amish children, whose Bible enjoins them to "be not conformed to this world," native means of enforcing compulsory vocational, correspondence course, or even sect-run training programs would serve to satisfy state educational goals almost as effectively. ${ }^{70}$

${ }^{74}$ See Note, Less Drastic Means and the First Amendment, 78 YALE L.J. 464, 466-68 (1969) (discussing ends versus means balancing). See also Ely, supra note 72, at 1486-87 (alternative-means test applicable to handbill cases where state goals are unrelated to the inhibition of expression).

75406 U.S. 205 (1972).

36 The mority opinion in Yoder does suggest, in its footnotes and summary remarks, that its decision rests upon an alternate-means analysis. See 406 U.S. at 234-36. Three members of the majority suggest in concurrence, however, that it is actually the diminished substantiality, in the higher grades, of the state's interest in education that ultimately renders compulsory attendance laws unnecessarily burdensome. See 406 U.S. at 238. The latter approach indicates a balancing of ends, not means, and a decision on the part of at least three Justices that the state's interest in education, beyond the eighth grade, is really not at all substantial-at least when balanced against the religious claims of Amish school children.

$\pi 406$ U.S. at 221.

${ }^{78} \mathrm{Id}$. at 216.

7 This inquiry into substantiality and available alternative means would work equally well in most of the other free exercise cases. See, e.g., Gallagher v. Crown Kosher Super Mkt., 366 U.S. 617 (1961); Braunfeld v. Brown, 366 U.S. 599 (1961); Prince v. Massachusetts, 321 U.S. 158 (1944). 
The broad protection of free exercise rights achieved under the alternate-means test does require some departure from Supreme Court precedent, ${ }^{80}$ but the departure is by no means considerable. Since at least $1890,{ }^{81}$ the free exercise clause has been construed to protect forms of public expression, as well as the mere possession of religious belief. The Supreme Court has extended the meaning of free exercise beyond the mere freedom of belief to include ${ }^{82}$ church worship, preaching from the pulpit, evangelism in the street, and the distribution of literature in public fora. In addition, the Supreme Court has itself resorted to the use of balancing tests in those free exercise cases that involve some overlap with issues of free speech. In the 1940 case of Cantwell $v$. Connecticut, ${ }^{83}$ for example, Jehovah's Witnesses challenged the validity of a state statute that required prior certification of religious solicitors in order to protect the public from fraudulent practices. Despite the substantiality of the government interest involved, ${ }^{84}$ the Court proceeded to consider whether such a regulation might "unduly" infringe first amendment rights, ${ }^{85}$ applying a clear-and-present-danger analysis even more protective of individual liberty than that afforded under a test of less drastic means. Similarly, in the 1941 case of Cox $v$. New Hampshire, ${ }^{86}$ although the Supreme Court upheld a licensing re-

In the 1944 case of Prince v. Massachusetts, 321 U.S. 158 (1944), for example, the Supreme Court upheld a conviction for violation of the state's child labor laws as applied to religious solicitations by a nine-year-old Jehovah's Witness. The Court recognized the substantiality of the state's interest in protecting its youth from the dangers of nighttime solicitation on the public streets and was unwilling to balance that interest against the parent's interest in sharing his religious practices with his own minor children. Under a less-drasticmeans approach, the Court should have recognized an exception in cases where minors are closely supervised by a parent or guardian. Contra, L. TrIBE, supra note $9, \S 14-10$, at 850 ("' $t]$ he government's purpose-protecting children from burdensome and exploitative labor-could not be achieved if adults were permitted to enlist the young as street proselytizers").

Similarly, the Supreme Court's refusal in Gallagher v. Crown Kosher Super Mkt., 366 U.S. 617 (1961), to carve out religious exemptions from Sunday closing law requirements for the benefit of Sabbatarians would be difficult to sustain under a test of less drastic means: a Sunday atmosphere that already abides the commercial operations of movie houses, sporting events, and gasoline stations can surely also tolerate the added commercialism of kosher meat and food markets in order to avoid a nonessential burdening of religious free exercise.

st See Davis v. Beason, 133 U.S. 333, 342 (1890); accord, United States v. Ballard, 322 U.S. 78, 86 (1944) ("The First Amendment has a dual aspect. It not only 'forestalls compulsion by law of the acceptance of any creed or the practice of any form of worship' but also 'safeguards the free exercise of the chosen form of religion.' Cantwell v. Connecticut, 310 U.S. 296, 303.").

\$2 See Everson v. Board of Educ., 330 U.S. 1, 32-33 (1947) (Rutledge, J., dissenting); Murdock v. Pennsylvania, 319 U.S. 105, 109 (1943).

s3 310 U.S. 296 (1940).

s Id. at 306.

ss Id. at 308.

312 U.S. 569 (1941). 
quirement, applicable to the organization of a religious parade on the public streets, it was unwilling to do so merely because the statute was, on its face, unrelated to the suppression of first amendment rights. ${ }^{87}$ The state's interest in highway safety was substantial, yet the Court again engaged in a form of balancing to determine if the incremental value in highway safety could justify the added burden on individual rights: "[T] is whether [government] control is exerted so as not to deny or unwarrantedly abridge the right of assembly and the opportunities for the communication of thought." 88 Testing religious free exercise claims by the more protective standards of free speech cases is not, therefore, without judicial support.

The coextensiveness of the free speech and free exercise provisions is strongly suggested in the Supreme Court's recent decision in Wooley $v$. Maynard. ${ }^{89}$ The claimants in Wooley, members of the Jehovah's Witnesses sect, had been repeatedly prosecuted under New Hampshire law for taping over the "Live Free or Die" motto on their vehicle license plates. Maynard refused to display the slogan because he found it "morally, ethically, religiously and politically abhorrent." 90 The Court's decision in favor of Maynard's right to freedom from coerced expression was based upon the broadest possible free expression grounds. Speaking in general terms of first amendment protection of "freedom of thought," the Court stated that "[a] system which secures the right to proselytize religious, political, and ideological causes must also guarantee the concomitant right to decline to foster such concepts." Having identified Maynard's interests as within the purview of the first amendment, the Court evaluated the state interest in readily identifiable license plates under a less-drastic-means test and found that the state's imposition on Maynard's rights could not be justified..$^{22}$ Although the Court never mentioned the free exercise clause, its explicit references to religious beliefs and to protection of the "sphere of intellect and spirit"93 suggest that the Court applied an alternative-means analysis to the totality of rights protected under both the free speech

87 Id. at 573-74.

ss Id. at 574 (emphasis added). For cases in which the overlap between the freedoms of religion and press seems also to have impelled the Court to a higher standard of scrutiny than that previously applied in free exercise cases alone, see Largent v. Texas, 318 U.S. 418 (1943), and Jamison v. Texas, 318 U.S. 413 (1943).

430 U.S. 705 (1977). But see note 67 supra.

" 430 U.S. at 713.

"Id. at 714 .

22 Id. at 715-17 (citing Shelton v. Tucker, 364 U.S. 479, 488 (1960)).

s3 430 U.S. 705, 715. 
and free exercise clauses.

In Sherbert $v$. Verner, ${ }^{94}$ the Supreme Court actually utilized a test of less restrictive means in assessing a claim of religious free exercise unrelated to other first amendment rights. In Sherbert, a state law that conditioned unemployment compensation benefits on availability for Saturday work was held unconstitutional as applied to a member of the Seventh Day Adventist Church: "For even if the possibility of spurious claims did threaten to dilute the fund and disrupt scheduling of work, it would plainly be incumbent upon the appellees to demonstrate that no alternative forms of regulation could combat such abuses without infringing First Amendment rights."95 Sherbert is thus good precedent for application of an alternative-means approach, which itself conforms to the fundamental principle of both religion clauses by maximizing the scope for expression of individual choice, permitting state interference with religious free exercise only when essential for the accomplishment of a substantial state purpose. As will be discussed, this expansive approach in turn provides a ready foundation for a similarly broad definition of religion in free exercise cases.

\section{B. A Narrow Establishment Prohibition}

The establishment clause is properly construed as prohibiting all laws respecting an establishment of any one religious or irreligious viewpoint. While this understanding removes many of the difficulties associated with Supreme Court doctrine, including the problem created by the Court's conflicting interpretations of the establishment and free exercise provisions, the proper scope of the prohibition remains troublesome. In its broadest form, the establishment principle would seemingly require the invalidation of any law that happens to advantage any particular religious view. Such a broad reading of the establishment prohibition is inherently unworkable, however, since almost any law may offend the religious sensibilities of some one individual. ${ }^{96}$ Secular public education, for example, certainly offends those who believe that no aspect of life should be divorced from religion, ${ }^{97}$ and, while state "monkey" laws

"374 U.S. 398 (1963).

is Id. at 407-08 (footnote omitted). Significantly, the Court supported this approach by citation to a number of speech cases. See, e.g., Talley v. California, 362 U.S. 60, 64 (1960); Martin v. City of Struthers, 319 U.S. 141, 144-49 (1943); Schneider v. State, 308 U.S. 147, 161 (1939).

* See Braunfeld v. Brown, 366 U.S. 599, 606 (1961); McGowan v. Maryland, 366 U.S. 420, 442 (1961); McCollum v. Board of Educ., 333 U.S. 203, 236 (1948) (Jackson, J., concurring).

" See Everson v. Board of Educ., 330 U.S. 1, 46-47 (1947) (Rutledge, J., dissenting). 
may advance sectarian beliefs premised on a biblical account of creation, the teaching of Darwinism might, conversely, be said to promote atheistic or agnostic views of life. ${ }^{88}$ The range of potential effects that any statutory provision might have on religious organizations is seemingly illimitable. Ultimately this is the source of inadequacy in the Supreme Court's own primary-effects test; ${ }^{99}$ everything conceivably has some effect on some form of religious opinion, and no clear standard has ever been provided to distinguish primary from secondary effects.

Theoretically this dilemma seems capable of resolution in two very different ways. If an establishment of religion is interpreted broadly to prohibit all laws that, although facially neutral, have the effect of favoring some particular religious view, religion can be defined quite narrowly in order to avoid illimitability. The indirect effects of any statute have then to be examined for possible establishment violations only within a limited range of religious principles or practices. This approach, however, is not particularly compatible with the fundamental value of individual choice that seems to underlie both the establishment and free exercise clauses. Worse yet, if the applicability of the establishment prohibition is limited to only a restricted range of religious views, then the judiciary is permitted to pick and choose among conscientiously held religious and irreligious views in order to determine which shall have the benefits, and which the burdens, of protection under the establishment clause. This very activity would seem to violate the strictures of a broadly construed establishment prohibition..$^{100}$

In principle at least, a more appropriate interpretation of the establishment clause would restrict the role of judicial definition in matters of religion and protect a broader range of religious opinion from governmental intrusion.This result can be accomplished by way of a narrowly drawn test-not of religion, but of establishment. If "an establishment of religion" is understood to preclude only those laws that on their face indicate a purpose of favoring or disfavoring particular religious views, then religion can be defined very broadly. ${ }^{101}$ Such an approach would not incapacitate legislative ac-

"see Epperson v. Arkansas, 393 U.S. 97, 113 (1968) (Black, J., concurring).

" "[T]o withstand the strictures of the "Establishment Clause there must be . . . a primary effect that neither advances nor inhibits religion." School Dist. v. Schempp, 374 U.S. 203, 222 (1963).

100 See note 129 infra.

i1 But cf. L. Trise, supra note $9, \$ 14-6$, at 826-31 (proposing a broad construction of religion for free exercise purposes and a narrow construction of religion for establishment purposes); id., $\S 14-8$, at 835 (" $t$ t] he requirement of a non-religious purpose would be impos- 
tion, since any statute facially neutral and secular would be constitutional despite any indirect or incidental effects it might have upon particular religious practices. This narrow interpretation of the establishment prohibition starts from the Kurland neutrality principle, ${ }^{102}$ under which, it will be recalled, "religion may not be used as a basis for classification for purposes of governmental action, whether that action be the conferring of rights or privileges or the imposition of duties or obligations."103

To the extent that the establishment clause proscribes any governmental preference of one religious or irreligious view over another, it necessarily prohibits the political use of religious classifications as a basis for the provision of benefits or burdens. Significantly, this is precisely the sort of analysis traditionally utilized in equal protection cases; racial categories, for example, form an impermissible basis for the districting of public school systems-or for almost any other process of legislative linedrawing. ${ }^{104} \mathrm{By}$ analogy to constitutional doctrine already developed by the Supreme Court in equal protection cases, therefore, a workable test can be formulated to effect a narrow understanding of the establishment prohibition.

First, if protection of any particular religious or irreligious expression is constitutionally required by the free exercise clause, that exception from the general rule of impartiality does not violate the establishment prohibition so long as similar exceptions are not denied to other religious or anti-religious groups. Examination under the establishment clause is thus unnecessary where a free exercise test of less drastic means has already determined the constitutional necessity of an exemption.

Second, if a classification benefiting a religious view is not constitutionally required by the free exercise clause, it must have more than a mere rational relationship to some valid secular purpose: its purpose or purposes must appear to be essentially unrelated to the advancement of any religious or irreligious view, as tested by scrutiny of various factors including "obvious effects." This purpose test is more stringent than either the Kurland approach or the secularpurpose strand of the Supreme Court's present three-part test. ${ }^{105}$

sible to apply if 'religion' . . . [in the establishment clause context] were given its broader, free exercise meaning") (footnote omitted).

102 See text and notes at notes 12-14 supra.

is Kurland, supra note 7. For an argument that cases arising under the establishment clause should be tested by the same (expansive) standard as applied in free exercise cases, see Note, supra note 36.

it Cf. Walz v. Tax Comm'n, 397 U.S. 664, 696 (1970) (Harlan, J., separate opinion) (tax exemption statute not drawn on religious lines).

${ }^{105}$ See, e.g., Meek v. Pittenger, 421 U.S. 349, 368 (1975); Board of Educ. v. Allen, 392 
The "essentially unrelated" test requires more than the existence of a plausible secular purpose; rather, it demands some more affirmative evidence that the statute does not purposely discriminate among religious or irreligious views. This more exacting scrutiny is necessary because most statutes have several purposes ${ }^{108}$ and because preferential treatment of religious over irreligious groups might otherwise be justified simply by reference to the broader, alternative purpose of ensuring a more secularly moral or lawabiding citizenry. ${ }^{107}$

Purpose can be tested by reference to a number of factors, including legislative or administrative history and the avowed intent of individual legislators. ${ }^{108}$ That one or two legislators make clear they have voted in favor of a law because it will benefit a particular religious group need not, of course, vitiate an otherwise unobjectionable statute. ${ }^{109}$ If, on the other hand, impermissible objectives were frequently advanced in legislative debate in support of that same program, the statutory scheme should become suspect. Because it is always difficult to determine the precise point at which the improper purposes of individual legislators become the improper purpose of a collegial body, ${ }^{110}$ however, secular purpose is most effectively tested by reference to the actual impact of a legislative action: ${ }^{111}$ if the obvious effect of a statute is to advance or hinder a

U.S. 236, 243 (1968); School Dist. v. Schempp, 374 U.S. 203, 222 (1963); accord, Gillette v. United States, 401 U.S. 437, 452 (1971) ("Still a claimant alleging 'gerrymander' must be able to show the absence of $a$ neutral, secular basis for the lines government has drawn.") (emphasis added).

If an exemption for free exercise purposes is not constitutionally required, it is permissible only if it can pass the test of secular purpose. The Court erred in Walz v. Tax Comm'n, 397 U.S. 664, 673 (1970), therefore, to the extent that it was willing to permit grants of tax exemption to religious institutions that were not constitutionally required and that were not similarly extended to irreligious groups. See note 65 supra.

113 In a slightly different context, see Arlington Heights v. Metropolitan Hous. Dev. Corp., 429 U.S. 252, 265 (1977); Note, Legislative Purpose, Rationality and Equal Protection, 82 YALE L.J. 123, 127-32, 141-46 (1972).

107 See McGowan v. Maryland, 366 U.S. 420 , $578-79$ n.10 (Douglas, J., dissenting). Contra, Ely, supra note 7, at 1324-25.

10 In two recent decisions, the Supreme Court has required proof of a racially discriminatory intent or purpose for violations of the fourteenth amendment equal protection clause. Arlington Heights v. Metropolitan Hous. Dev. Corp., 429 U.S. 252 (1977); Washington v. Davis, 426 U.S. 229 (1976). Among the relevant factors in determining purpose, the Court suggested in Arlington Heights, were the following: the impact of the official action, the sequence of events leading up to the challenged decision, and the legislative or administrative history. 429 U.S. at $266-68$.

109 Cf. Washington v. Davis, 426 U.S. 229, 253 (1976) (Stevens, J., concurring) ("A law conscripting clerics should not be invalidated because an atheist voted for it.").

110 Brest, Palmer v. Thompson: An Approach to the Problem of Unconstitutional Legislative Motive, 1971 Sur. CT. REv. 95, 124.

iII This article takes the position that the Court must make the effort to look beyond a 
particular religious interest, then the state's purpose is necessarily less believably secular. This kind of "obvious effects" approach corresponds to the approach taken by the Supreme Court in decisions such as Gomillion v. Lightfoot, ${ }^{112}$ a case of racial classification held impermissible under the fifteenth amendment. In Gomillion, the Court held that the gerrymandering of Tuskegee, Alabama, into the shape of a 28-sided figure was unconstitutional because it could have no purpose other than the disenfranchisement of blacks in municipal elections. A similar willingness to probe behind the stated purpose of any law benefiting a particular religious group would ensure that the establishment provision, while narrowly drawn, could not be circumvented by merely appending to such law a list of spurious secular aims. In short, where statutes though conceivably neutral in purpose "howsoever speciously defined, obviously discriminate," such obvious effects require that the law be invalidated. ${ }^{113}$

This approach to legislative purpose should be distinguished from the Court's own "primary effects" strand of the establishment test. The "obvious effects" test probes the possible existence of a

stated legislative purpose and focus upon examination of obvious effects as the basis for such an inquiry. Examination of legislative motive is another possible means of looking beyond expressed purpose. From the standpoint of religion clause doctrine, examination of motive would not be inappropriate. Whether secular purpose should be tested by reference to motive as well as to effect depends ultimately upon more general considerations of the propriety or practicability of such a judicial inquiry. For a discussion of motive analysis, see, e.g., Brest, supra note 110 (arguing that the Court should avoid motive analysis whenever possible); The Supreme Court, 1976 Term, 91 HARv. L. Rev. 70, 163-76 (1977) (suggesting motive analysis might be displaced by a "stigmatizing effects" approach).

112364 U.S. 339 (1960). In Gomillion, the Court found it "difficult to appreciate what stands in the way of adjudging a statute having this inevitable effect invalid," id. at 342, though it also noted that the respondents in the case "never suggested, either in their brief or in oral argument, any countervailing municipal function which [the act] is designed to serve." Id. See also Castaneda v. Partida, 430 U.S. 482 (1977) (discriminatory purpose inferred from underrepresentation of Mexican-Americans on grand juries); Arlington Heights v. Metropolitan Hous. Dev. Corp., 429 U.S. 252 (1977) (citing Gomillion); Washington v. Davis, 426 U.S. 229 (1976). Disproportionate impact "may for all practical purposes demonstrate unconstitutionality because in various circumstances the discrimination is very difficult to explain on nonracial grounds." Id. at 242 (Stevens, J., concurring).

Of course, not every instance of disproportionate effect necessarily substantiates an improper purpose. See, e.g., Arlington Heights, 429 U.S. at 266-67; Washington, 426 U.S. at 248.

Dicta in Supreme Court religion cases also support some scrutiny of purpose beyond the facial neutrality of a statute. See, e.g., Hunt v. McNair, 413 U.S. 734, 741 (1973). Cf. Gillette v. United States, 401 U.S. 437, 443-46, 452 (1971) (scrutiny of legislative history developed secular purpose for facially religion-favoring statute); Schwarz, supra note 7, at 693 (the establishment clause prohibits aid "which has as its motive or substantial effect the imposition of religious belief').

"13 Gomillion v. Lightfoot, 364 U.S. 339, 342 (1960). 
hidden, unconstitutional purpose; the "primary effects" test stops at the actual impact of the legislation, invalidating statutes that substantially benefit religion whether or not such benefits are indicative of intent. ${ }^{114}$ The attention to purpose-requiring the identification of impact with intent-reflects the narrower doctrine of religious establishment that the present analysis seeks to provide. The two tests do, however, involve much the same kind of judicial determination. In McGowan v. Maryland, ${ }^{115}$ for example, the Court seems actually to have used the "primary effects" test in order to double-check its application of the more fundamental secular purpose requirement:

We do not hold that Sunday legislation may not be a violation of the "Establishment" Clause if it can be demonstrated that its purpose-evidenced either on the face of the legislation, in conjunction with its legislative history, or in its operative effect-is to use the State's coercive power to aid religion. ${ }^{110}$

Moreover, though the Court has continued to insist that its secular purpose and "primary effects" tests are distinct, the facts on which it has relied to determine primary effects are often indistinguishable from the kind of information it might use to evaluate legislative purpose. Thus, in Meek $v$. Pittenger, ${ }^{117}$ four Justices joined in invalidating Pennsylvania's provision of instructional equipment and auxiliary services to nonpublic schools because "more than 75\% [of the schools qualifying under the program] are church-related or religiously affiliated."118 Such an impact could suggest an illegitimate purpose as easily as an unacceptable primary effect.

It is important to bear in mind the nature of the effect-and purpose-that is impermissible under the establishment clause.

I1 Cf. Ely, supra note 7, at 1318 (the primary effect test should be read "as an evidentiary reference, to denote the sort of impact which will support an inference of pro- or anti-religious motivation.").

115366 U.S. 420 (1961).

116 Id. at 453. See also Epperson v. Arkansas, 393 U.S. 97 (1968). Although the state in Epperson apparently did not advance any secular purpose at all in defense of its ban on the teaching of evolution, Justice Black did suggest in concurrence that a conceivable secular purpose might lie in the state's removal of a controversial subject from the classroom. Id. at 112-13. The majority of the Court, however, was not willing to overlook the obviously partisan nature of the restriction: "[T]here is no doubt that the motivation for the law was . . . to suppress the teaching of a theory which, it was thought, "denied' the divine creation of man." Id. at 109.

117421 U.S. 349 (1975).

118 Id. at 364 . Similar data were used in Sloan v. Lemon, 413 U.S. 825, 830 (1973), where 90 percent of the children whose parents would have been entitled to tuition reimbursement were enrolled in religiously affiliated schools. 
The Constitution prohibits the purposeful advantaging of one religious or irreligious opinion over another, not of religion over nonreligion. If a large proportion of the beneficiaries of a particular statute are related to a particular church, this does not necessarily mean that some anti-religious or religious groups are unconstitutionally disadvantaged. This is particularly so where, as in our society, religious groups command more attention than anti-religious movements. A law exempting all religious and irreligious associations from property taxation would probably have the effect, for example, of exempting many more religious than irreligious organizations. This effect alone, however, should not render the exemption invalid: irreligious groups might, in fact, be benefited in proportion to their general presence in the community, or those who hold anti-religious views might simply not feel the same need to mobilize as do the members of many religious sects. Where, however, one religious group in particular is effectively benefited almost to the exclusion of other religious or irreligious groups, it is difficult to escape the conclusion, as in Gomillion, that such an obviously extreme imbalance in effect was actually intended. Use of an obvious effects test provides, therefore, a reasoned basis for inferring the presence of an impermissible legislative purpose from the facts of such previously decided cases as Everson v. Board of Education, ${ }^{119}$ where the only nonpublic school children who stood to benefit from the public reimbursement of school bus fares attended Catholic parochial schools, Lemon $v$. Kurtzman, ${ }^{120}$ where the nonpublic school beneficiaries of the challenged Rhode Island and Pennsylvania state-aid programs were approximately 95 percent Catholic, and Committee for Public Education and Religious Liberty $v$. Nyquist, ${ }^{121}$ where almost 85 percent of the nonpublic schools eligible for maintenance and repair grants were affiliated with the Catholic Church.

Under the establishment clause, a test of purpose need not involve consideration of the importance of state goals. So long as the statutory purpose is unrelated to religious matters, its triviality should be irrelevant. Nevertheless, because first amendment rights are fundamental within our constitutional system, at least some degree of means scrutiny should be required in order to prevent any unnecessary effects in matters of religion. ${ }^{122} \mathrm{~A}$ less-drastic-means

II' 330 U.S. 1, 4 n.2 (1946).

12. 403 U.S. 602 (1971).

121413 U.S. 756, 768 (1973).

12 Cf. Department of Agriculture v. Moreno, 413 U.S. 528, 534-38 (1973) (denial of food stamp assistance to all households containing unrelated members in order to prevent abuse sweeps too broadly); Reed v. Reed, 404 U.S. 71, 76 (1971) (mandatory preference to men for 
test would also serve to double-check the impartiality of any legislative enactment in the area of religious establishment. Under such a test, a court might inquire whether the incidental influence on religious or irreligious opinion, although insufficient to suggest an impermissible purpose, is nevertheless greater than is essential for the furtherance of an otherwise valid secular purpose. ${ }^{123}$ If available alternative means could as adequately accomplish the state's purpose with less effect on religious or irreligious opinion, then the government should be obligated to utilize such available alternative means. It should be noted that while this test is similar to the alternate-means test to be applied in free exercise cases, its limitation on legislative action is much less strict: given the existence of a secular purpose, this requirement would not necessitate the use of less effective alternative means. There are instances, however, where the test would still serve to restrain governmental influence in religious affairs.

In the 1968 case of Board of Education v. Allen, ${ }^{124}$ for example, the Supreme Court upheld New York's program of lending textbooks to nonpublic school children because it recognized the existence of a valid secular purpose in furthering "the educational opportunities available to the young." 125 As Justice Douglas argued in dissent, ${ }^{128}$ however, the law worked to the advantage of particular religious groups, because it allowed sectarian officials to exercise their preferences in selecting textbooks for their pupils, with the local public school boards exercising only a veto over any such selections that were not, in fact, secular or nonreligious. The system, as Douglas warned, had the potential effect of placing those textbooks most compatible with sectarian principles in the hands of parochial school children at public expense. Under an alternative-means analysis, this criticism of the New York program is sound and should have led to the program's invalidation: the incidental assistance to religion exceeds that essential for the furtherance of the state's interest in providing secular textbooks to school children. The state could have approved, instead, the loan of only those texts actually used in public school classes, an alternative that would have eliminated the unnecessary aspect of parochial school choice and control over the books received. Since alternative means were available that

appointment as estate administrators is an improper means to reduce probate court workload).

${ }^{123}$ Cf. United States v. O'Brien, 391 U.S. 367, 377 (1968) (similar test employed).

124392 U.S. 236 (1968).

$125 \mathrm{Id}$. at 243.

124 Id. at 255-56. 
would have as effectively accomplished New York's educational purpose, the statute involved in the Allen case should have been held unconstitutional.

To recapitulate, the following three-step inquiry provides a principled basis for analyzing claims of religious establishment:

1. Is the religious classification constitutionally required by the free exercise guarantee (if so, there is no establishment problem);

2. If not, is its purpose, as tested by its most obvious effects, unrelated to matters of religion; and

3. Is the incidental effect on religious or irreligious opinion greater than essential for the accomplishment of the state's secular purpose?

This rather narrowly drawn test of religious establishment permits, as indicated earlier, ${ }^{127}$ the use of a broad definition of religion in cases arising under the establishment clause.

\section{A Definitional Approach to Rejigion}

The foregoing analysis of the two religion clauses demonstrates the extent to which both clauses are compatible with a broad meaning of religion. ${ }^{128} \mathrm{~A}$ narrow construction of the establishment prohibition minimizes the risk that large numbers of statutes will be invalidated simply because they happen to affect activities that might broadly be defined as religious. At the same time, recognition of the distinction between nonreligion and irreligion permits special protection under the free exercise clause of a wide variety of religious claims without danger of creating an impermissible establishment. Moreover, because both the free exercise and establishment clauses implement a fundamental principle of individual choice, the accommodation of such choice would seem to require an expansive and highly subjective definitional approach to both clauses. Since the freedom of belief protected by the free exercise clause surely includes the right to define one's own views, too narrow a judicial

${ }^{127}$ See discussion at notes 109-112 supra.

123 Recent commentators have suggested that the separate development of the two religion clauses has made a "bifurcated" definition of religion necessary. See note 9 supra. But the Constitution itself poses an objection to this approach, since it uses the word only once for the two clauses. See Everson v. Board of Educ., 330 U.S. 1, 32 (Rutledge, J., dissenting). It has been the purpose of the first two sections to demonstrate that the need for a "bifurcated" definition arises only from a misunderstanding of first principles and an attendant misconstruction of the two clauses. 
definition of religion might effect an impermissible establishment of religion. ${ }^{129}$

\section{A. Religion Under the Free Exercise Clause}

The only explicit Supreme Court attempt to formulate a constitutional definition of religion can be found in the 1890 decision in Davis v. Beason: ${ }^{130}$

The term "religion" has reference to one's views of his relations to his Creator, and to the obligations they impose of reverence for his being and character, and of obedience to his will. It is often confounded with the cultus or form of worship of a particular sect, but is distinguishable from the latter. ${ }^{131}$

Given the number of beliefs the Court itself is now willing to recognize as religious, even when they involve no fundamental concept of God or Creator, ${ }^{132}$ this understanding of religion is clearly inadequate for present constitutional purposes. The Davis definition does, however, indicate a very early rejection of cultus as a necessary component of religious faith. ${ }^{133}$ More recent Supreme Court opinions have added the understanding that religion involves belief systems that are inherently nonrational: in affairs of religion, men not only "may believe what they cannot prove,"134 but it may even be that "[b]elief in what one may demonstrate to the senses is not faith." 135 It is this nonrational aspect of religion that seems to account for the Court's willingness to tolerate public-school presentations of the Bible or of other religious materials so long as they are "presented

129 See Weiss, supra note 12, at 604; cf. Zorach v. Clauson, 343 U.S. 306,318 n.4 (1952) (Black, J., dissenting) ("A state policy of aiding 'all religions' necessarily requires a governmental decision as to what constitutes 'a religion.' Thus is created a governmental power to hinder certain religious beliefs by denying their character as such. ... This provides precisely the kind of censorship which we have said the Constitution forbids.").

130133 U..S. 333 (1890).

131 Id. at 342. The definitions enunciated in the more recent conscientious objector cases are constructions of statutory-not constitutional-language. See Welsh v. United States, 398 U.S. 333, 342-44 (1970); United States v. Seeger, 380 U.S. 163, 165-66 (1965). But see Note, supra note 9, at 1064 and authorities cited in note 68 supra, arguing that these cases establish constitutional principles.

${ }^{132}$ E.g., United States v. Seeger, 380 U.S. 163, $180-83$ (1965); Torcaso v. Watkins, 367 U.S. 488, 495 n.11 (1961); accord, United States v. Seeger, 380 U.S. at 191 (Douglas, J., concurring).

${ }^{133}$ Accord, Everson v. Board of Educ., 330 U.S. 1, 32 (1946) (Rutledge, J., dissenting). But see Welsh v. United States, 398 U.S. 333, 353 (1970) (Harlan, J., concurring) (statutory construction); Fellowship of Humanity v. Alameda, 153 Cal. App. 2d 673, 693, 315 P.2d 394, 406 (1957).

134 United States v. Ballard, 322 U.S. 78, 86 (1944).

13s Id. at 94 (Jackson, J., dissenting). 
objectively," or as an "historic viewpoint"136 from fully rational as opposed to emotional perspectives.

But if religious belief is inherently nonrational and if it does not require the existence of a cult to organize and define its precepts, then it is difficult to identify a principled basis for excluding any belief actually held by some individual to be religious. The Supreme Court has moved in this direction in the conscientious objector cases, reading the statutory exemption of religious belief to include "intensely personal" convictions: "In such an intensely personal area, of course, the claim of the registrant that his belief is an essential part of a religious faith must be given great weight."137 Such a highly individualistic approach to religion would not, of course, have been acceptable to the Supreme Court at the time of its earliest considerations of the free exercise guarantee. ${ }^{138}$ But any other approach seems incapable of accommodating not only the two to three hundred identifiable sects existing in this country, ${ }^{139}$ but also the variety of individualistic doctrines the Supreme Court itself has recognized as religious. ${ }^{140}$

A definitional approach to religion based solely on the individual's own characterization of his belief might appear to be judicially illimitable. An even less desirable alternative, though, is a formulation that would permit the Court to prescribe the parameters of religious faith. This dilemma may be resolved, and the meaning of "religion" minimally objectified, by testing a claimant's characterization of his beliefs against a traditionally accepted notion of religion as involving duties and obligations to conform to the standards of a unified belief system that cuts across and directs more than a single aspect of an individual's life. ${ }^{141}$ This understanding of religion

เ3 Epperson v. Arkansas, 393 U.S. 97, 106 (1968); School Dist. v. Schempp, 374 U.S. 203, 225 (1963).

137 United States v. Seeger, 380 U.S. 163, 184 (1965).

138 See, e.g., The Late Corp. of the Church of Jesus Christ of Latter-Day Saints v. United States, 136 U.S. 1, 49 (1890) ("One pretense for this obstinate course is, that their belief in the practice of polygamy, or in the right to indulge in it, is a religious belief. . . . This is altogether a sophistical plea."). Cf. Davis v. Beason, 133 U.S. 333, 342-43 (1890) (stating that religious practices "must be subordinate to the criminal laws of the country").

130 See Braunfeld v. Brown, 366 U.S. 599, 606 (1961).

16 See, e.g., United States v. Seeger, 380 U.S. 163, 180-83 (1965). See also the factual description of the "I Am" movement, as well as Justice Jackson's dissenting opinion in United States v. Ballard, 322 U.S. 78, 79-80, 94 (1944).

III See Wisconsin v. Yoder, 406 U.S. 205, 219 (1972) ("In sum, the unchallenged testimony of acknowledged experts . . . , almost 300 years of consistent practice, and strong evidence of a sustained faith pervading and regulating respondents' entire mode of life support . . . [respondents'] claim."). See also Welsh v. United States, 398 U.S. 333, 340 (1970) ("Most of the great religions of today and of the past have embodied the idea of a Supreme Being ... who communicates to man in some way a consciousness of what is right and should 
as a multidimensional belief system is reflected in the congressional distinction between religious belief and "essentially political, sociological, or philosophical views." 142 It is also embedded in the sincerity test the Supreme Court has applied in the conscientious objector cases: the exemption for religious training and belief protects "religious beliefs . . . to which all else is subordinate or upon which all else is ultimately dependent." 143 Though marginally restrictive of the right of individuals to define for themselves the nature of their religious beliefs, such a requirement serves to introduce a necessary objective basis for the judicial scrutiny of highly unusual religious claims. ${ }^{144}$

As the judicial inquiry turns to those beliefs that depart most drastically from conventional concepts of religion, this definitional approach might still seem practically unmanageable, particularly if the protection afforded to the expression of such individually defined views is also to be expansively implemented under an alternative-means test. Exemptions from otherwise valid legislation would have to be made available to each individual who insists that his conduct is premised on religious or irreligious grounds. But the Court has been able to manage claims of similar peculiarity and variety in the free speech area where individuals have also insisted that their conduct, though in violation of the law, involved pro-

be done, of what is wrong and therefore should be shunned."); United States v. Macintosh, 283 U.S. 605, 633-34 (1931); Davis v. Beason, 133 U.S. 333, 342 (1890) (religious liberty involves "man's relations to his Maker and the obligations he may think they impose.").

Incorporating an objective element into the definitional approach to religion does not establish a set of tenets that an individual must hold in order to be considered religious. Instead, the judicial concern is with the role that the belief system plays in the individual's life. The requirement of beliefs that cut across more than one aspect of the individual's life is similar to that proposed by one recent commentator, see Note, supra note 9, at 1066-67, 1072-75 (adopting a functional definition based on Tillich's concept of "ultimate concern"). Under this scheme, only those beliefs to which all else is subordinate fall within the scope of the religion clauses. The use of "ultimate concern" as a constitutional touchstone, however, has its shortcomings. Most significant is the definitional problem inherent in the term "ultimate." For example, the ultimate concern test would deny free exercise protection to a belief that is "subordinate or capable of compromise." Id. at 1075. Must a belief be "ultimate" only within the context of the free exercise claim, or must the belief be uncompromised in all contexts? The commandment "thou shall not kill" has often been subordinated to a need to defend oneself, one's family, one's country, and indeed, one's religious beliefs. The multidimensionality standard set forth in this article would better accommodate the subordination of pure religious principles to the demands of daily life.

162 Military Selective Service Act, 50 U.S.C. app. 8456 (j) (1970).

14 United States v. Seeger, 380 U.S. 163, 176 (1965). See Note, supra note 9, at 1075 (the Court in Seeger and Welsh relied upon the ultimate concern test espoused by Tillich).

14 Although the existence of a cultus is not necessary to establish a belief as religious, it may facilitate the demonstration of sincerity; the fact that an individual's beliefs are "shared by an organized group," Wisconsin v. Yoder, 406 U.S. 205, 216 (1972), does indicate that others, at least, also find such beliefs to be religious. 
tected, if unusual (and from the Court's perspective, low value) forms of communication. In cases of symbolic speech such as draft card burning ${ }^{145}$ and flag desecration, ${ }^{148}$ the focus has not been on whether the conduct at issue constitutes speech, but rather on whether the assertedly speech-related conduct can be protected under the constitutional tests of the first amendment. By analogy, emphasis in cases of free exercise need not be placed so much on whether a particular set of beliefs fits within the confines of traditional religious belief, but on whether state interference with such assertedly religious or irreligious conduct can be justified under an alternative-means analysis.

Moreover, the alternative-means analysis will itself place a limit on the granting of free exercise exemptions. The test of alternative means necessarily presumes that any exception permitted in one case of free exercise will also be made available in any other case in which similar claims are either religiously or irreligiously based. Thus, in balancing free exercise claims against governmental interests, courts will necessarily weigh the degree to which alternative means could conceivably impair such interests if all conscientious, religious, or irreligious claims were to be recognized. Such an approach should also serve to limit the creation, on a case-by-case basis, of exemptions for individual claims that could not be justified if considered together in a single suit. ${ }^{147}$

In addition, free exercise protection need be extended only to the expression of opinions the individual claimant seems sincerely to believe are religious or irreligious. Although the Court has not been explicit in this regard, first amendment rights in the area of free speech have already been premised on some showing of sincerity. It is doubtful, for example, that the Court would invoke the guarantee of free speech in order to invalidate a breach of peace statute as applied to a drunk convicted of raucously singing on the public streets: even though his singing may have been sufficiently intelligible to communicate some ideas, his motives as a speaker would be constitutionally suspect. Similarly, in the area of religious free exercise it is not unreasonable to require that individually-

us United States v. O'Brien, 391 U.S. 367, 369, 376 (1968).

14 Spence v. Washington, 418 U.S. 405, 409 (1974) (per curiam).

17 This limitation also restricts the Court's ability to pick and choose among religious claimants in order to protect those most sympathetic to traditional or favored notions of religious belief. What the Court extends to one religiously motivated individual, it must be prepared to do for all. To the extent that the Court may have suggested otherwise, see Wisconsin v. Yoder, 406 U.S. 205, 235-36 (1972) and Sherbert v. Verner, 374 U.S. 398, 409-10 (1963), the Court was in error. 
defined religious views be sincerely or conscientiously held in order to qualify for first amendment protection. Indeed, the Supreme Court has refused to preclude such inquiry into the sincerity with which potentially fraudulent religious beliefs are held, ${ }^{148}$ and has actually construed the statutory exemption for conscientious objector status to require a showing that religious beliefs are, in fact, "sincerely," "honestly," and "truly held."149

A workable test of religion for purposes of the free exercise clause might thus be stated to include any multidimensional system of beliefs that an individual claimant sincerely asserts to be religiously held. ${ }^{150}$ Such a test is not without its problems. It does not always provide a clear judicial standard by which the individual can determine when his conduct qualifies for free exercise consideration. If the individual does not know, or perhaps is merely unsure of how to classify his beliefs, no constitutional definition can help him. Still, the approach comports well with a highly individualistic understanding of religion. ${ }^{151}$ Although the Supreme Court has insisted that it need not accept a claimant's own perception of his beliefs in applying constitutional standards, ${ }^{152}$ it is certainly more logical, as well as more consonant with principles of individualism, to defer to the individual's own understanding of what only he can ever really know. If an individual asserts that his conduct is unrelated to religious expression, or if he does not choose to claim that his conduct is religiously motivated, then the broad protection of the free exercise clause should simply not be made available to him..$^{153}$

The more recent religious claims raised in the lower federal courts demonstrate the sufficiency of this definitional approach to religious free exercise. Since 1973, for example, courts in two different federal circuits have had to decide whether the protections of the free exercise clause extend to the practices of the Church of the

16 United States v. Ballard, 322 U.S. 78, 84 (1944).

14 United States v. Seeger, 380 U.S. 113, 166-67, 176, 185 (1965).

150 A workable test of irreligion might be stated to include any multidimensional system of belief sincerely asserted to be held in opposition to all forms of belief systems religiously held by others. Unless opposition to a particular form of religion is itself religiously based, opposition to only one or a few religions is not sufficiently multidimensional to warrant protection under the free exercise clause and should have to rely upon the free speech guarantee for protection.

is1 See text and notes at notes 30-37 supra.

152 Welsh v. United States, 398 U.S. 333, 341 (1970). Welsh first characterized his beliefs as nonreligious but later changed his mind.

1ss Cf. Weiss, supra note 12, at 605 ("When a man acts publicly in a domain where the normal expectations are of secular contentions, he must make it clear that his claims are made as elements of a faith which describes the nature of things about which he is making the claims."). 
New Song (or Eclatarian faith). One court ${ }^{154}$ found the Eclatarian faith to be a religion within the meaning of the first amendment; another has disagreed. ${ }^{155}$ Fact findings indicate that the Church of the New Song was founded by Dr. Harry W. Theriault who, while an inmate in a federal prison, claimed to receive "prophetic messages from 'Eclat' informing him that he was the 'Eclatarian Nazarite." "158 Theriault's following spread as he was transferred within the federal penitentiary system. The central principle and focus of the Eclatarian faith is anti-authoritarian, concerned primarily with the destruction of repressive rulers within the prison system in particular, and within the government and judiciary in general. ${ }^{157}$ This belief system does not seem, therefore, to involve duties or principles of conduct that cut across more than one aspect of life:

Rather than urging upon its followers any particular theology or philosophy of life, the Church of the New Song appears to encourage a relatively non-structured, free-form, do-as-youplease philosophy, the sole purpose of which is to cause or encourage disruption of established prison discipline for the sake of disruption. ${ }^{158}$

While these principles might well have been sincerely held by Theriault's prison followers, their narrow focus suggests that they were not, in fact, held as sincere religious beliefs warranting protection under the religious free exercise clause of the first amendment.

Similarly, the religious bona fides of a member of the NeoAmerican Church were rightly rejected by a federal district court in the case of United States $v$. Kuch. ${ }^{159}$ Appellant Kuch claimed to be "the primate of the Potomac"180 within the hierarchy of the NeoAmerican Church and asserted that it was her religious duty to engage in the regular use of the sacraments of marijuana and LSD. The trial court found that the Church published a "Catechism and Handbook,"161 and made available "communion sets' with chalice and cup" and "pipes for 'sacramental use." "162 But other findings

is Remmers v. Brewer, 361 F. Supp. 537 (S.D. Iowa 1973), aff'd per curiam, 494 F.2d 1277 (8th Cir. 1974).

iss Theriault v. Silber, 391 F. Supp. 578 (W.D. Tex. 1975), on remand from Theriault v. Carlson, 495 F.2d 390 (5th Cir. 1974), vacated and remanded, 547 F.2d 1279 (5th Cir. 1977).

1s Theriault v. Carlson, 495 F.2d 390, 391 n.1 (5th Cir. 1974).

157 Id. at 394.

1ss Theriault v. Silber, 391 F. Supp. 578, 582 (W.D. Tex. 1975), vacated and remanded, 547 F.2d 1279 (5th Cir. 1977).

159 288 F. Supp. 439 (D.D.C. 1968).

16 Id. at 443 .

101 Id.

102 Id. at 445. 
of fact belied the sincerity with which such practices were conducted as a form of religion. "[T]he so-called 'Catechism and Handbook' of the Church [contain] the pronouncements of the Chief Boo Hoo . . . . Each member carries a 'martyrdom record' to reflect his arrests. The Church symbol is a three-eyed toad. . . . The Church key is, of course, the bottle opener."183 The narrowness of Kuch's belief system seems also to have influenced the court:

What is lacking in the proofs received as to the Neo-American Church is any solid evidence of a belief in a supreme being, a religious discipline, a ritual, or tenets to guide one's daily existence. It is clear that the desire to use drugs and to enjoy drugs for their own sake, regardless of religious experience, is the coagulant of this organization and the reason for its existence. ${ }^{164}$

Again, therefore, even though every member of the Neo-American Church may have sincerely believed in the principles and practices espoused, their sincerity as a religious group was rightfully denied by the court. The single unifying principle of the Church, an antiestablishment ethos focused on the use of drugs, lacked the broader range of duties and principles that should be required for religious protection under the free exercise clause.

\section{B. Religion for Establishment Clause Purposes}

Thus far, the Supreme Court has managed to escape the problem of defining religion for establishment clause purposes, since most of the establishment cases it has decided have involved disputes over public aid to religious groups that have never claimed to be anything but religious. When officials have acted in ways that support these groups, the controversy has centered not on whether religion is involved, but on whether an impermissible establishment has occurred. In Malnak $v$. Yogi, ${ }^{105}$ the TM case, however, all of the allegedly religious organizations denied that their teachings had anything to do with religion. Their assertion of the right to teach TM in the public schools has thus posed a unique constitutional problem. At issue, ultimately, is the question whether or not the defendants' own definition of religion-which should control (subject to tests of sincerity and multidimensionality) in free exercise cases-should also control for purposes of the establishment clause.

10 Id. at 444.

iu Id. (footnote omitted).

tw 440 F. Supp. 1248 (D.N.J. 1977). 
Since protection of individual choice underlies both religion clauses of the first amendment, at least in principle, the same presumptive understanding of religious belief, derived from those whose beliefs are at issue, should apply in establishment as well as free exercise cases. Although, in most establishment cases, the beliefs at issue have allegedly been advantaged, rather than disadvantaged, ${ }^{188}$ those who have chosen to identify themselves with a particular set of beliefs still remain in the best position to characterize the nature of their own views. ${ }^{167}$ The judicial inquiry would focus on whether the doctrines at issue constitute a nonrational belief system involving duties or principles that cut across more than a single aspect of life. Moreover, a test of sincerity can also be used under

14 The problem of applying a definition of religion can also arise in establishment cases involving a claim that a purportedly religious group has been disfavored by being denied advantages available to other religious or irreligious groups, a problem analagous to free exercise cases in which a group is denied special protection because it does not satisfy the minimum criteria of religion. See text at notes 154-164 supra. See, e.g., Missouri Church of Scientology v. State Tax Comm'n, 560 S.W.2d 837 (Mo. 1977), appeal dismissed, 47 U.S.L.W. 3220 (U.S. Oct. 2, 1978). Similarly, consider the problem posed by the use of the Universal Life Church ministry as a tax avoidance device. See note 5 supra.

In Missouri Church of Scientology, the Supreme Court of Missouri upheld a ruling of the State Tax Commission that the Church of Scientology was ineligible for the state's tax exemption of property used for religious purposes. The court found that the Church had failed to qualify as a true religion because the tenets of Scientology do not include belief in a deity. 560 S.W.2d at 840 . The court stated: "The term religious worship in the commonly accepted sense includes as a necessary minimum a belief in the Supreme Being of the universe." Id. Since the definition of religion fashioned by the court would exclude not only Scientology, but Buddhism, Taoism, and Ethical Culture, see Torcaso v. Watkins, 367 U.S. 488, 495 n.11 (1961), it is manifestly unacceptable. Nevertheless, the United States Supreme Court, faced with the Church's claim that Missouri's definition of religion was impermissibly narrow, dismissed the appeal without opinion. Missouri Church of Scientology v. State Tax Comm'n, 47 U.S.L.W. 3191,3220 (U.S. Oct. 2, 1978). Both the Missouri court's decision and the Supreme Court's dismissal, however, can be reconciled with the approach advocated by this article. In establishing its claim as a religious institution, the Church of Scientology presented only one witness, whose credibility, the Tax Commission found, was subject to serious question. 560 S.W.2d at 843 n.6. In light of the Commission's factual findings, the case could easily have been decided on the sincerity ground, leaving the Missouri court's "Supreme Being" requirement as dictum. Id. at 845 (Seiler, J., concurring in result). Indeed, the Supreme Court, in dismissing for want of a substantial federal question, may have regarded the Tax Commission's findings as an adequate state ground for decision and therefore found it unnecessary to reach the Church's constitutional challenge.

167 Cf. Fowler v. Rhode Island, 345 U.S. 67, 70 (1953) (" $[1] t$ is no business of courts to say that what is a religious practice or activity for one group is not a religion under the protection of the First Amendment."). But cf. Weiss, supra note 12, at 606 (where a movement claims to be religious, its claims are tested by whether the movement asks for assent to specifically "supernatural' claims traditionally connected with religion"). For another attempt to establish more objective standards of religious association, see Comment, Defining Religion: Of God, the Constitution and the D.A.R., 32 U. CHI. L. REv. 533, 550-52 (1965). Any more precise definition, however, if it is also sufficiently broad to encompass most modern forms of religion, will inevitably raise severe establishment problems whenever ethical or moral issues are discussed in the public schools. See id. at $554 \mathrm{n} .102$. 
the establishment clause to limit the possibility of fraud. Where, as in most establishment cases, an organization's self-definition is at issue, this test of sincerity can be double-checked by reference to whether or not a significant portion of that organization's membership individually understands the organization to be one that is associated with religion. ${ }^{168}$

If the organization's understanding of itself is sincerely religious or irreligious, then the purpose, obvious effects, and less-drasticmeans analysis discussed earlier come into play. If its sincere understanding is unrelated to religion, then by definition any governmental support of its programs is also unrelated to religion, or secular in purpose, and examination under the establishment clause ends without further scrutiny. This approach should be sufficient in all cases that involve the advantaging of particular groups. It is also consistent with a number of Supreme Court decisions delineating the free exercise rights of religious organizations to include selection of their own clergy, administration of their own regulations, and elaboration of their own doctrine for their memberships without judicial interference. ${ }^{169}$

This definitional approach is insufficient, however, to implement all of the important policies of the establishment clause. The

183 Should a large proportion of an organization's membership treat its doctrines as religious, then that organization is itself precluded from denying any religious association for purposes of the establishment clause. This serves, for example, to prevent an organization from gaining access to the public schools for the transmission of its "nonreligious" views, at the same time that its individual members may claim the privileges of the free exercise clause on the basis of their own individual "religious" beliefs. Of course, no organization should be deemed religious merely because some isolated segment of its members happen to derive some religious content from its teachings (even though those members-if sincere-would still be protected under the free exercise guarantee).

169 In the 1952 case of Kedroff v. Saint Nicholas Cathedral, 344 U.S. 94 (1952), the Court was required to consider the constitutionality of a New York statute consolidating all churches formerly subject to the Patriarch of Moscow under authorities newly selected by a convention of North American churches. The effect of the law was to prevent a priest designated by the Russian Orthodox Church from using a cathedral in New York City. In an eight to one decision, the Court invalidated the statute, holding it in violation of "the ecclesiastical right" of a hierarchical church organization to select its own clergy, regulate its own adminis. tration, and operate its own churches independently of state control. Id. at 107-08, 116, 119. This interpretation of the free exercise guarantee was reaffirmed by the Court in 1969, when it denied civil courts the power to resolve controversies of religious doctrine taking place within the hierarchy of an organized church. In Presbyterian Church v. Mary Elizabeth Blue Hull Memorial Presbyterian Church, 393 U.S. 440 (1969), a jury decision "whether the actions of the general church 'amount to a fundamental or substantial abandonment of the original tenets and doctrines of the [general church]," " $i d$. at 443, was held to violate the church's free exercise rights under the first amendment. These cases suggest that courts should be hesitant to interpose their own understandings of religion on groups whose organizational hierarchies can define and elaborate their principles for their memberships. Accord, Serbian E. Orthodox Diocese v. Milivojevich, 426 U.S. 696 (1976) (church policy and administration). 
establishment clause does not merely prevent the support of particular religious or irreligious groups; it also serves to enforce a general political impartiality between all religious and irreligious views. Thus, even if a group can demonstrate that it is not religious in character, a law advancing its interests should still run afoul of the establishment prohibition if its activities serve to advance either religious or irreligious opinion. Similarly, laws that operate to the advantage of religious or irreligious views, in general, without reference to any particular religious organizations should be invalidated. Thus, even if a daily recitation could be composed that would satisfy all organized religious groups, that recitation should still be prohibited from use in the public schools because such use could be perceived as advancing the cause of religion in general, ${ }^{170}$ to the detriment of irreligious or atheistic views.

One approach to this problem is to focus on the symbols that have traditionally been identified with religious belief. Sermons, Bible-reading, and devotional ceremonies are obvious accoutrements of religion. ${ }^{171}$ Other examples might include the ritualized use of incense, candlelighting, kneeling, or bowing. A constitutional reliance upon such institutional symbols does have the disadvantage of emphasizing more traditional approaches to religion. ${ }^{172}$ Any political use of symbols or ceremonies so unusual in form as to be unassociated in the public mind with religion, however, would not be very likely-even if it escaped establishment prohibition-to provide very strong support for any particular religious view.

By isolating those activities most likely to promote religion generally, this sort of judicial identification of traditionally used religious symbols can serve to refine not only the test of institutional sincerity, but also the basic establishment tests for secular purpose and less drastic means outlined earlier. ${ }^{173}$ If a group chooses to utilize the sort of institutionalized ceremony or ritual customarily associated with religion, this factor should be considered relevant to the

170 Engel v. Vitale, 370 U.S. 421, 430-31 (1962).

${ }^{17 \prime}$ Cf. School Dist. v. Schempp, 374 U.S. 203, 216, 223-24 (1963) (Bible reading); Murdock v. Pennsylvania, 319 U.S. 105, 112 (1943) (sermons).

172 Professor Alston argues that "the best way to explain the concept of religion is to elaborate in detail the relevant features of an ideally clear case of religion and then indicate the respects in which less clear cases can differ from this." Alston, Religion, in 7 EncycLopediA of PhLosophy 140, 142 (P. Edwards ed. 1967). Alston identifies nine "religion-making characteristics," one of which is ritual acts focused on sacred objects. Id. at 141. But as Alston notes, "ritual can be sharply de-emphasized . . . as in Protestantism; it can even disappear altogether, as with the Quakers," id. at 142, yet, the term "religion" unmistakably applies to the Protestant and Quaker faiths.

${ }^{173}$ See text at notes 104-126 supra. 
sincerity of that group's denial of any religious affiliation. Similarly, any political or statutory use of such institutional symbols should also call for special scrutiny of the state's claims of a nonreligious purpose. If, for example, a public school were to require five minutes of silence every morning in order to calm its students down or enable them to engage in private contemplation, this would seem to serve a valid secular interest without any obvious or nonessential effects on religion. If instead, however, the school were to go one step further and require that that five minutes be spent in a kneeling position, the regulation could be serving the same secular purpose, but its obvious effect would indicate an underlying purpose of advancing religious affiliation. Under an alternative-means analysis, the requirement would also fail, since it utilizes a religious symbol or ritual that is not essential to the secular goal of providing a few minutes of tranquility, contemplation, or rest.

In sum, therefore, religion can be defined institutionally for establishment purposes:

1. by the organization or group that is advantaged, but its sincerity is a question of fact to be determined by reference to whether:

a. the group's doctrines constitute a nonrational belief system involving principles and duties that cut across more than one aspect of life; and

b. the group utilizes the sort of ritualized ceremony or symbolism traditionally associated with religion; and.

2. by reference to the use made of institutional symbols of religion in all cases where challenge is made to an alleged establishment of religious or irreligious opinion unrelated to the support of any particular religious or irreligious group.

Because this definitional approach relies primarily upon an institution's own understanding of itself, it can be effective with minimal judicial involvement required to identify only the more obvious religious symbols. In the Malnak case, for example, ${ }^{174}$ where the teaching of Transcendental Meditation was challenged as a governmental establishment of religion, the defendant organizations claimed that their teaching of TM was wholly unrelated to religion. Defendants' membership, including both teachers and students of TM, ${ }^{175}$ seemed also uniformly to believe that their involvement with the program in no way created an affiliation with religion. Although

17440 F. Supp. 1284 (D.N.J. 1977).

${ }^{175}$ Memorandum, supra note 27, at 1-2. 
defendants claimed to help individuals attain a level of increased energy and efficiency, TM does not itself appear to prescribe any particular content for other aspects of the meditator's life. Rather, Transcendental Meditation seems useful in "achieving a state of deep rest and mental alertness."178

Transcendental Meditation does, however, appear to draw heavily upon a number of symbols traditionally associated with religion. The initiation ceremony, as described in plaintiff's brief, ${ }^{177}$ embodies many of the trappings of religious ritual, including ceremonial use of candles, incense, and a devotional "puja" chant. The following is only a portion of the puja chant recited during the initiation ceremony:

Guru Dev, Shri Brahmananda, bliss of the Absolute, transcendental joy, the self-Sufficient, the embodiment of pure knowledge which is beyond and above the universe like the sky, the aim of 'Thou art That' and other such expressions which unfold eternal truth, the One, the Eternal, the Pure, the Immovable, the Witness of all intellects, whose status transcends thought . . . , to Shri Guru Dev, I bow down.

The blinding darkness of ignorance has been removed by applying the balm of knowledge. The eye of knowledge has been opened by Him and therefore, to Him, to Shri Guru Dev, I bow down.

Offering a handful of flowers to the lotus feet of Shri Guru Dev, I bow down. ${ }^{178}$

The defense contended that the puja "is no more than a purely secular ceremony, arising out of the cultural traditions of the Indian subcontinent, honoring the line of teachers who have preserved the technique."178 But it is also possible that these organizations simply chose to deny any religious affiliation in order to gain an audience with persons who would not otherwise agree to participate in the TM program.

The court found defendants' denials of religious belief clearly disingenuous. ${ }^{180}$ Whether or not defendants were sincere in their

176 Id. at 4-5.

in Brief in Support of Cross Motion for Partial Summary Judgment at 4, Malnak v. Yogi, 440 F. Supp. 1284 (D.N.J. 1977).

17440 F. Supp. 1284, 1307 (D.N.J. 1977).

17 Memorandum, supra note 27, at 5-6.

100 The Court was willing to recognize "the sincerity with which defendants adhere to their teachings," but not the sincerity of their denial that such adherence was in any way religious. Malnak v. Yogi, 440 F. Supp. 1284, 1319 (D.N.J. 1977). The record was found not 
denial of religious affiliation, however, their extensive use of religious symbolism should still have required the court's decision that they be prohibited from teaching TM in the public schools. ${ }^{181}$ At the very least, the TM program operates to advantage religion in general in the eyes of its pupils through the transmission and publication of religion's most traditional accoutrements. Under part two of the proposed definitional test, the symbolic content of the TM initiation ceremony seems sufficient to trigger the purpose and lessdrastic-means tests under the establishment clause. And, while the teaching of TM may serve to advance a valid state interest in teaching a method of relaxation capable of maximizing individual productivity, it does not appear to pass the alternate-means test, since other forms of meditation ${ }^{182}$ are probably every bit as effective without drawing as heavily upon religious symbolism for effect. The difficult issues raised by the $T M$ case seem capable, therefore, of a principled resolution on the basis of the tests for religious establishment outlined above.

\section{ConcLÚsion}

The theoretical approach proposed in this article offers a sound, principled foundation for continuing judicial development of religion clause doctrine and serves to resolve many of the difficult issues posed in recent religion clause cases. Deference to individual determinations of religious belief necessarily involves some rethinking of the Supreme Court's pronouncements in both the free exercise and establishment contexts. The Court's refusal to exempt Orthodox Jewish merchants from Sunday closing laws, its approval of tax exemptions for religious organizations, and even its summary affirmance of state laws punishing religiously motivated polygamy warrant reconsideration. So too, the Court's prohibition of most

\footnotetext{
"to raise the slightest doubt as to the facts or as to the religious nature of the teachings of the Science of Creative Intelligence." Id. at 1327.

Although the court in Malnak did not frame its opinion in the terms of this paper and even explicitly rejected reliance on any sincerity test, $i d$. at 1318 , its decision can be understood as resting upon a judgment that defendant organizations were not sincere in their denials of religious belief because TM, when taught in conjunction with the Science of Creative Intelligence: (a) involved more than mere meditation, invoking a belief in an "omnipotent," "eternal," "self-sufficient," "omnipresent" intelligence which is "the source of everything," "perpetually active," "perfect" and "just"-i.e., a belief cutting across more than one aspect of life; and (b) utilized the sort of ritualized ceremony traditionally associated with religion. See, e.g., id. at 1290, 1302-03, 1305-10, 1323 \& n.25.

${ }_{181}$ Contra, L. TruBE, supra note $9, \$ 14-6$, at 829 ("[t]he teaching of TM as an elective course should . . . be deemed permissible.").

182 See, e.g., H. Benson, The RehaXation Response (1975).
} 
forms of aid to parochial schools might be relaxed so long as irreligious groups were similarly advantaged under state law. For the most part, however, such a reexamination of these precedents is already required to bring the Court's earlier decisions into harmony with recent religion clause developments.

The proposed reconciliation of the religion clauses would serve to minimize the theoretical conflict underlying the Court's application of the two clauses, while limiting judicial intrusion into the realm of private religious belief. Properly understood, the religion clauses can guarantee an expansive freedom for individuals to choose and express their own definitions of religion without, at the same time, serving fraudulent or insincere claims for special protection and privilege. This understanding comports well with other constitutional principles and requires only a limited departure from existing Supreme Court doctrine. It also serves to leave unimpaired the special protection that religious conscience has traditionally enjoyed within our constitutional system. 